Jurnal Geocelebes Vol. 4 No. 1, April 2020, 41 - 45

\title{
PENGARUH STRUKTUR GEOLOGI TERHADAP KEMUNCULAN MATA AIR PANAS DAERAH SULILI PINRANG SULAWESI SELATAN
}

\author{
Emi Prasetyawati Umar ${ }^{1 *}$, Habibie Anwar ${ }^{1}$, Jamal Rauf Husain ${ }^{2}$, Sitti Muharni ${ }^{1}$ \\ ${ }^{1}$ Jurusan Teknik Pertambangan, Universitas Muslim Indonesia, Makassar, Indonesia \\ ${ }^{2}$ Departemen Teknik Geologi, Universitas Hasanuddin, Makassar, Indonesia \\ *Corresponding author. Email: emiprasetyawati.umar@umi.ac.id
}

Manuscript received: 24 February 2020; Received in revised form: 9 April 2020; Accepted: 13 April 2020

\begin{abstract}
Abstrak
Kondisi dan struktur geologi suatu daerah merupakan aspek penting karena data geologi dapat memberikan informasi tentang karakteristik lapisan batuan yang berguna di dalam ilmu panas bumi. Olehnya itu, dilakukan penelitian untuk mengeksplorasi lebih detail mengenai analisis struktur geologi mata air panas dan pengaruh kemunculan mata air panas tersebut, sebagai penunjang data eksplorasi yang belum pernah diteliti sebelumnya. Tujuan penelitian ini adalah menganalisis struktur geologi mata air panas dan mengetahui pengaruh geologi terhadap munculnya mata air panas di Daerah Sulili. Metode yang digunakan adalah metode sampling dan analisis data kekar. Struktur geologi yang terjadi pada Daerah Sulili adalah struktur kekar yang terdapat pada litologi batuan tufa. Kemunculan mata air panas diakibatkan adanya pengaruh struktur geologi berupa kekar dan sesar geser yang berkembang pada daerah tersebut.
\end{abstract}

Kata Kunci: Kekar; Litologi; Sesar; Sampling.

\begin{abstract}
The condition and geological structure of area is an important thing because the geological data can provide informations about the characteristics of a stratum which is useful for the geothermal science. Therefore, This research was held to explore more detail of the geological structures of hot springs analysis and and its effect on the appearance of those hot springs as a support data for exploration that has never been studied before. The purpose of this studies was to analyze the geological structure of hot springs and determine the geological effects of the emergence of hot springs in the Sulili area. The method which was used is sampling and joint data analysis. The geological structure of the Sulili area is joint structure which is found in tufa rock lithology. In addition, the emergence of hot springs is the effect of geological structures of the form of joint and transform fault that is spread in that area.
\end{abstract}

Keywords: Fault; Joint; Lithology; Sampling.

\section{Pendahuluan}

Sulawesi adalah salah satu pulau di Indonesia yang memiliki potensi energi alternatif berupa geothermal energy atau energi panas bumi yang keberadaannya disebabkan oleh proses geologi berupa vulkanisme dan tektonik (Jamaluddin dan Umar, 2017). Secara umum, geologi merupakan ilmu yang mempelajari tentang bumi baik stuktur, sejarah, komposisi pembentuk bumi dan segala proses pembentukannya. Energi yang terjadi dalam geologi secara umum berasal dari gaya endogen dan eksogen. Gaya yang berasal dari dalam bumi atau endogen akan mengakibatkan terjadinya gempabumi dan aktivitas vulkanik sedangkan yang 
berakibat pada pembentukan bentang alam dan terjadinya pelapukan serta erosi adalah gaya yang berasal dari luar bumi atau disebut juga dengan gaya eksogen (Dearman, 1991). Proses geologi ini akan menyebabkan terbentuknya batuan dengan karakteristik ciri khusus dan akan menjadi fenomena geologi yang akan dimanfaatkan sebagai potensi Sumber Daya Geologi (Bronto dan Hartono, 2006). Data geologi merupakan hal yang sangat penting karena dapat memberikan gambaran informasi mengenai kekuatan serta karakteristik lapisan tanah dan batuan yang sangat berguna di dalam ilmu panas bumi (Dearman, 1991).

Energi panas bumi merupakan energi yang tersimpan dalam bentuk air panas atau uap panas pada kondisi geologi tertentu di kedalaman beberapa kilometer dalam kerak bumi. Sistem panas bumi merupakan suatu daur hidrologi air (air tanah dan air hujan). Dalam mekanisme terjadinya proses tersebut, berhubungan dengan sumber panas (heat source) yang bertemperatur tinggi sehingga terbentuk air panas pada batuan yang berpermeabilitas tinggi. Uap air dan air panas tersebut akan muncul ke permukaan melalui struktur kekar dan sesar yang terbentuk (Tutu et al., 2015).

Berdasarkan observasi lapangan Daerah Sulili (Gambar 1) menunjukkan salah satu bentuk manifestasi panas bumi berupa mata air panas (Gambar 2). Manifestasi panas bumi terjadi karena adanya rekahan yang mengindikasikan fluida panas ke luar pada permukaan. Rekahan dapat terbentuk karena adanya struktur geologi (Umar dan Jamaluddin, 2018). Olehnya itu, dilakukan penelitian untuk mengeksplorasi lebih detail mengenai analisis struktur geologi mata air panas Daerah Sulili Kecamatan Paleteang Kabupaten Pinrang Provinsi Sulawesi Selatan sebagai data penunjang eksplorasi geologi di daerah tersebut yang belum pernah diteliti sebelumnya.

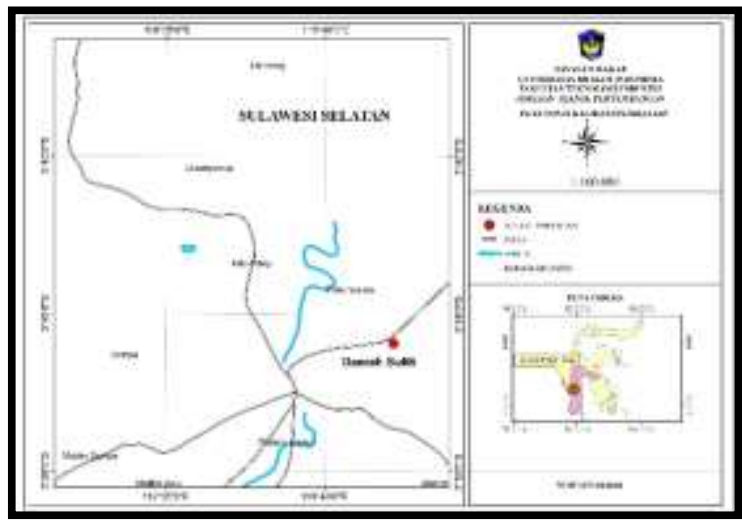

Gambar 1. Peta Lokasi Penelitian.

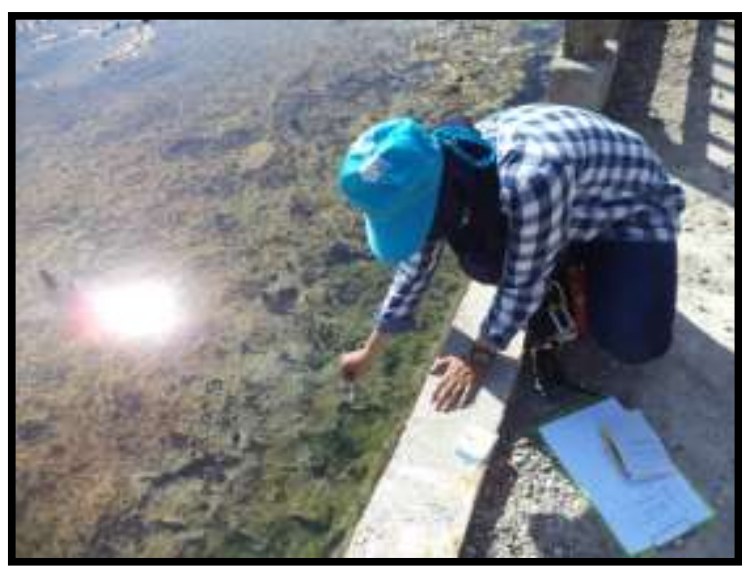

Gambar 2. Kegiatan pengukuran suhu air pada salah satu sumber mata air panas di Daerah Sulili (tampak mata air telah dibeton).

\section{Metode Penelitian}

Observasi dan pengambilan data secara langsung di area penelitian merupakan metode yang digunakan dalam penelitian ini. Adapun langkah - langkah dari penelitian ini adalah:

\section{Pengambilan data}

Pengambilan data berupa sampel batuan dan juga memperhatikan kondisi geologi pada Daerah Sulili atau titik pengambilan sampelnya. Melakukan penentuan titik pengambilan data dengan menggunakan GPS geologi (Global Positioning System). Pengamatan singkapan, meliputi deskripsi singkapan, pengambilan foto singkapan, titik koordinat dan data kekar pada singkapan batuan. 


\section{Pengolahan dan evaluasi data}

Data yang diperoleh dari lapangan adalah data struktur geologi, koordinat lokasi, dokumentasi kegiatan penelitian. Data sekunder berupa peta lokasi, kondisi geologi regional Daerah Sulili dan literatur yang berhubungan dengan judul penelitian.

\section{Analisis data kekar}

Tahap analisis data kekar menggunakan Diagram Roset. Diagram Roset digunakan untuk mengetahui arah dari bidang perlapisan dan kekar pada struktur batuan dan mineral.

\section{Hasil dan Pembahasan}

Struktur geologi Daerah Sulili meliputi jenis struktur geologi dan mekanisme pembentukannya. Berdasarkan jenisnya, struktur geologi yang dijumpai pada Daerah Sulili berupa struktur kekar. Kekar atau rekahan adalah jenis struktur batuan dalam bentuk bidang pecah (Haryanto, 2005). Kenampakan kekar ditunjukkan pada Gambar 3.

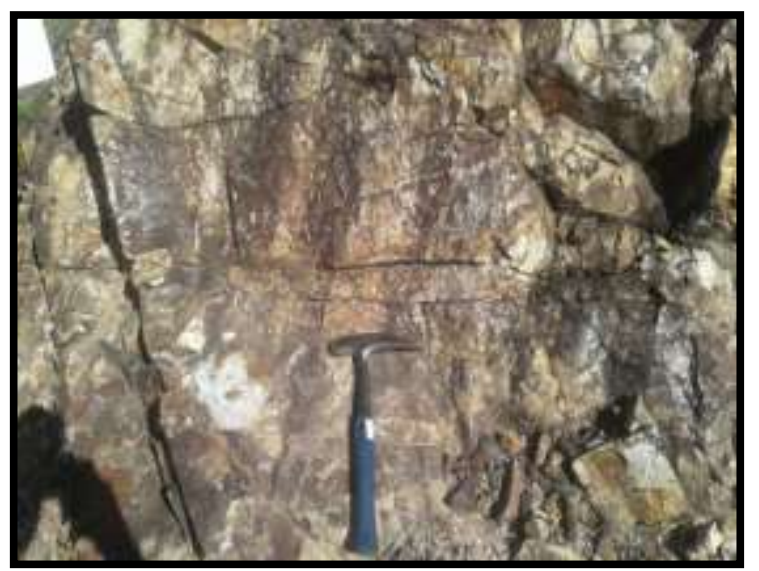

Gambar 3. Kenampakan Kekar (N140E).

Penentuan jenis struktur kekar Daerah Sulili didasarkan pada hasil pengukuran kekar yang dapat dilihat pada Tabel 1 . Kekar yang dijumpai di lapangan terdapat pada litologi tufa. Kenampakan kekar saling berpasangan dan relatif sejajar. Beberapa pengukuran kekar pada tufa ada yang tidak sistematis sehingga tidak dapat dijadikan untuk penentuan arah gaya dan kebanyakan kekar muncul pada arah yang sama. Jumlah data kekar yang diolah yaitu 100 data.

Tabel 1. Hasil Pengukuran Kekar Daerah Sulili.

\begin{tabular}{ccc}
\hline No & Strike $\left(\mathbf{N} .{ }^{\circ} \mathbf{E}\right)$ & Dip \\
\hline 1. & 75 & 70 \\
2. & 259 & 71 \\
3. & 90 & 45 \\
4. & 70 & 65 \\
5. & 330 & 67 \\
6. & 143 & 76 \\
7. & 250 & 77 \\
8. & 72 & 81 \\
9. & 215 & 78 \\
10. & 85 & 90 \\
11. & 142 & 75 \\
12. & 325 & 78 \\
13. & 258 & 70 \\
14. & 85 & 90 \\
15. & 213 & 76 \\
16. & 148 & 54 \\
17. & 95 & 50 \\
18. & 142 & 75 \\
19. & 329 & 66 \\
20. & 328 & 81 \\
\hline
\end{tabular}

Hasil pengukuran data kekar dan interpretasi peta topografi Daerah Sulili dengan arah tegasan utama maksimum yaitu $\left(\sigma_{1}\right) \mathrm{N} 75^{\circ} \mathrm{E}$, tegasan utama menengah $\left(\sigma_{2}\right) \quad \mathrm{N} 335^{\circ} \mathrm{E}$ dan arah tegasan utama minimum $\left(\sigma_{3}\right) \mathrm{N} 345^{\circ} \mathrm{E}$. Maka diperoleh Diagram Roset yang dibuat secara manual terlihat pada Gambar 4.

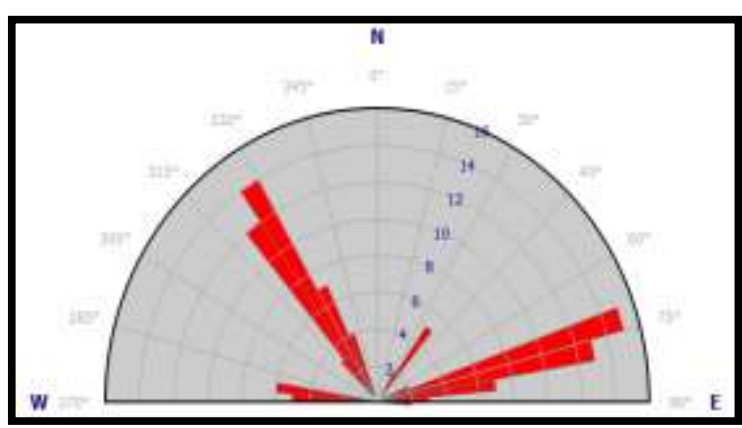

Gambar 4. Diagram Roset. 


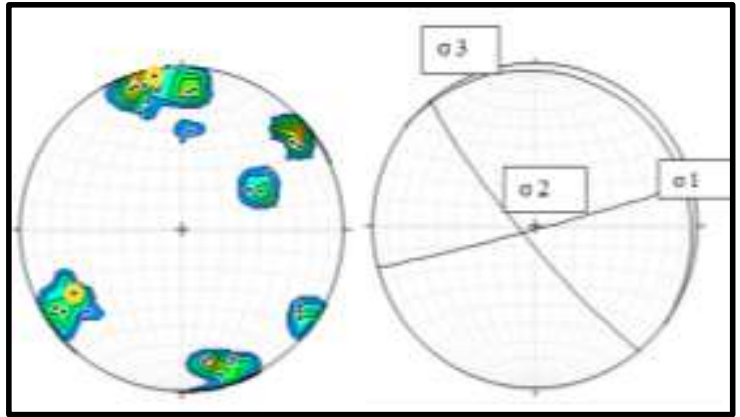

Gambar 5. Proyeksi stereografi berdasarkan data kekar pada litologi tufa.

Gambar 5 merupakan hasil proyeksi stereografi berdasarkan data kekar yang telah diolah secara manual dan menunjukkan bahwa sesar yang berkembang pada Daerah Sulili adalah sesar geser.

Kemunculan mata air panas Daerah Sulili ditinjau dari aspek analisis struktur geologi disebabkan oleh adanya struktur kekar dengan tipe kekar sistematik (Asikin, 1979) dan berdasarkan hasil analisis terhadap data lapangan serta kaitannya dengan kondisi tektonik regional maka jenis sesar yang bekerja pada Daerah Sulili berupa sesar geser.

Kekar - kekar ini merupakan media keluarnya air panas ke permukaan dan secara struktur geologi regional, struktur yang ada berupa patahan dan Sesar Walanae. Sesar Walanae termasuk sesar yang aktif dan arah pergerakannya relatif mengarah ke arah baratlaut - tenggara yang terletak pada lokasi kemunculan mata air panas Daerah Sulili Kecamatan Paleteang Kabupaten Pinrang (Sukido dan Koesoemadinata, 1997).

\section{Kesimpulan}

Kemunculan mata air panas di Daerah Sulili dipengaruhi oleh adanya struktur geologi berupa kekar dengan tipe kekar sistematik. Kekar - kekar ini merupakan media keluarnya mata air panas di permukaan. Berdasarkan hasil analisis terhadap data lapangan serta kaitannya dengan tektonik regional maka sesar yang bekerja pada Daerah Sulili berupa sesar geser. Pengaruh geologi terhadap munculnya mata air panas ditandai dengan adanya struktur yang berupa sesar aktif dan kekar yang berkembang pada daerah tersebut.

\section{Ucapan Terima Kasih}

Terimakasih yang tak terhingga kepada Lembaga Penelitian dan Pengembangan Sumberdaya Universitas Muslim Indonesia Makassar (LP2S-UMI) dan Pemerintah Daerah Kabupaten Pinrang Provinsi Sulawesi Selatan, terkhusus di Daerah Sulili atas segala bentuk dukungan dalam pelaksanaan hingga ke tahap publikasi penelitian ini.

\section{Daftar Pustaka}

Asikin, S. 1979. Dasar-Dasar Geologi Stuktur. Departemen Teknik Geologi, Institut Teknologi Bandung.

Bronto, S dan Hartono, U. 2006. Potensi Sumber Daya Geologi Di Daerah Cekungan Bandung dan Sekitarnya. Jurnal Geologi Indonesia. 1 (1), pp 918.

Dearman, W.R. 1991. Engineering Geological Mapping. ButterworthHeinemann Ltd., Oxford: United Kingdom.

Haryanto, I. 2005. Penelitian Struktur Geologi dan Kaitannya Terhadap Kemungkinan Adanya Potensi Emas Primer Daerah Gunung Astana Bogor, Jawa Barat. Jurnal Portalgaruda. 3(2), pp. 83-91.

Jamaluddin dan Umar, E.P. 2017. Karakteristik Fisik dan Kimia Mataair Panas Daerah Barasanga Kabupaten Konawe Utara, Provinsi Sulawesi Tenggara. Jurnal Geocelebes, 1 (2), pp. 62-65.

Sukido, D. Satria dan S. Koesoemadinata, 1997. Peta Geologi Lembar Enrekang, Sulawesi Selatan, skala 1:100.000, 
Pusat Penelitian dan Pengembangan Geologi, Bandung.

Tutu, R., Subaer dan Usman. 2015. Studi Analisis Karakteristik dan Mikrostruktur Mineral Sedimen Sumber Air Panas Dearah Sulili Di Kabupaten Pinrang. Jurnal Sains dan Pendidikan Fisika, 11 (2), pp. 192-201. Umar, E.P. dan Jamaluddin. 2018. Karakteristik Endapan Sinter Travertin Panas Bumi Barasanga Kabupaten Konawe Utara, Sulawesi Tenggara. Jurnal Geocelebes, 2 (2), pp. 64-69. 